\title{
Management of high-level radioactive waste in Germany: roads from storage towards disposal - need and options for action
}

\author{
Saleem Chaudry ${ }^{1}$, Angelika Spieth-Achtnich ${ }^{1}$, and Wilhelm Bollingerfehr ${ }^{2}$ \\ ${ }^{1}$ Öko-Institut e. V., 64295 Darmstadt, Germany \\ ${ }^{2}$ BGE TECHNOLOGY GmbH, 31224 Peine, Germany \\ Correspondence: Saleem Chaudry (s.chaudry@ oeko.de)
}

Published: 10 November 2021

\begin{abstract}
The road towards final disposal of high-level radioactive waste (HAW) produced in Germany requires extensive and foresighted management. To date, HAW has been stored in dual-purpose casks inside 15 interim storage facilities. Finally, it is disposed of in a deep geological repository. A site-selection process for this repository, taking into account the whole national territory, started in 2017.

The road from interim storage to final disposal is not yet planned in detail: neither temporally nor spatially nor technically. Important parameters are still unknown. The last operating licenses of the existing interim storage facilities, originally built to last for up to 40 years, will end in 2047, and a concept for prolonged interim storage does not exist. The dates for the decision on the repository site and the start of its operation are plagued by uncertainties, as well as the development of safety concepts for different potential host rocks or knowledge on the long-time behavior of disused fuel assemblies during dry interim storage. According to the German siteselection law (Deutscher Bundestag, 2017) the siting decision for the final repository is planned to be made in 2031; Thomauske and Kudla (2016) drew up timelines for the site-selection process to end between 2059 and 2096.

The research project WERA - Management of high-level radioactive waste in Germany: Roads from storage towards disposal - addressed these uncertainties through the development of different design options for the four main steps of the German road to disposal and of a variety of scenarios combining these steps, covering a broad range of potential future designs of the road to disposal. These scenarios have been analyzed in detail. Need for technical and political action along the road to final disposal has been identified. Options for action were named, and their preconditions and consequences were listed. The design options and the scenarios derived form the basis of societal discourse on the disposal of high-level radioactive waste. Thus, the research project WERA contributes toward the politically and societally active integration of the different disposal steps (interim storage, receiving storage facility, waste conditioning, and final disposal).
\end{abstract}

Kurzfassung. Die Entsorgung für in der Bundesrepublik Deutschland produzierte hochradioaktive Abfälle erfordert ein umfassendes und vorausschauendes Wegemanagement. Diese Abfälle lagern derzeit in Transportund Lagerbehältern in 3 zentralen sowie 12 Standortzwischenlagern. Zu ihrer Entsorgung ist die Errichtung eines Endlagers im tiefen Untergrund vorgesehen. Ausgehend vom gesamten Staatsgebiet wird aktuell ein Standortauswahlverfahren durchgeführt.

Der Entsorgungsweg vom Zwischenlager bis zum verschlossenen Endlager ist bisher weder zeitlich noch räumlich noch technisch ausgearbeitet. Wesentliche Größen sind unbekannt. Die letzten Genehmigungen der Standortzwischenlager laufen 2047 aus, ein Konzept für eine verlängerte Zwischenlagerung existiert nicht. Die Zeitpunkte der Standortentscheidung und Inbetriebnahme eines Endlagers sind mit großen Ungewissheiten behaftet. Das gilt auch für Sicherheitskonzepte zur Endlagerung in den verschiedenen, in Frage kommenden Wirtsgesteinen oder das Wissen über das Langzeitverhalten ausgedienter Brennelemente während der trockenen Zwi- 
schenlagerung. So wird z. B. nach dem Standortauswahlgesetz (Deutscher Bundestag, 2017) die Festlegung des Endlagerstandortes für das Jahr 2031 angestrebt; Thomauske und Kudla (2016) gehen von einem Ende des Standortauswahlverfahrens zwischen 2059 und 2096 aus.

Im vom Bundesministerium für Wirtschaft und Forschung (BMWi, FKZ 02E11789) geförderten Forschungsvorhaben WERA - Wegemanagement bei der Entsorgung hochradioaktiver Abfälle in Deutschland - wurden für jeden Entsorgungsschritt von der Zwischenlagerung bis zur Endlagerung Optionen zur Ausgestaltung entworfen, mit dem Ziel, eine möglichst breite Schar möglicher zukünftiger Verläufe des Entsorgungsweges darzustellen. Daraus wurden Szenarien für den gesamten Entsorgungsweg entwickelt, die ein breites Spektrum möglicher zukünftiger Ausgestaltungen abdecken. Aus der Analyse dieser Szenarien konnten technische und politische Handlungsbedarfe abgeleitet und zur Verfügung stehende Handlungsoptionen mit den jeweils notwendigen Voraussetzungen und Konsequenzen für den weiteren Entsorgungsweg aufgezeigt werden. Die Optionen für Entsorgungsschritte und die darauf basierenden Szenarien bieten eine Grundlage für den gesellschaftlichen Diskurs. Das Vorhaben schafft so eine Basis, die Integration der verschiedenen Entsorgungsschritte (Zwischenlagerung, Konditionierung, Transporte bis hin zur Endlagerung) politisch und gesellschaftlich aktiv zu gestalten.

\section{References}

Deutscher Bundestag: Gesetz zur Suche und Auswahl eines Standortes für ein Endlager für hochradioaktive Abfälle (Standortauswahlgesetz - StandAG), Standortauswahlgesetz vom 5. Mai 2017 (BGB1. I S. 1074), das zuletzt durch Artikel 2 Absatz 16 des Gesetzes vom 20. Juli 2017 (BGB1. I S. 2808) geändert worden ist, 2017.
Thomauske, B. and Kudla, W.: Zeitbedarf für das Standortauswahlverfahren und für die Errichtung eines Endlagers. KDrs. 267, 2016. 